\title{
The Impact of Market Relocation to Roadway and Sidewalk Functions at Patiunus Street Pekalongan
}

\author{
Azhar Hasna Rany ${ }^{1, a)}$, R. Siti Rukayah ${ }^{2}$, Suzanna Ratih Sari ${ }^{2}$ \\ ${ }^{1}$ Architectural Engineering Master's Students, Engineering Faculty, Diponegoro University \\ 2 Architectural Engineering Master's Lectures, Engineering Faculty, Diponegoro University \\ ${ }^{\text {a) }}$ Corresponding author: hasnarany@gmail.com
}

\begin{abstract}
The more advance establishment of the country leads to the more developed economic progress. The economic activities require better supporting facilities and infrastructure. Market is one of infrastructure that can support economic activities. In addition, it requires a market location, it also requires a road to distribute the commodities in or out of the city. Roadway and sidewalk are supporting infrastructures that improve the economy in a country. One of market in Pekalongan city, Banjarsari Market's was in fire. Then Banjarsari market was relocated in Patiunus Street. This research was conducted in Patiunus street, the sidewalk that was used for Banjarsari market relocation. The market relocation in the roadway and sidewalks can affect road functions and road users' activities. Especially in the balancing interaction factor between the pedestrians and the vehicles, the safety factor of adequate space for pedestrians, the facilities offered a pleasurable experience on the sidewalk, the availability of public facilities unites, becomes supporting elements of the sidewalk. This research used the qualitative method and used three data collection techniques: direct observation, questionnaire, and documentation. The conclusion of this study is the existence of the Banjarsari market relocation on Jalan Patiunus affected the function of roads and sidewalks. By analyzing the result of the field survey and questionnaire to the road user and sidewalk users from Patiunus street, it can be concluded that the four standards for sidewalk (the balancing interaction between the pedestrians and the vehicles, safety factor, the facilities offered a pleasurable experience on the sidewalk and the availability of public facilities unites and becomes supporting elements of the sidewalk). Therefore, Patiunus street can have good functions for road user and sidewalk users.
\end{abstract}

Keywords: market relocation, roadway functions, sidewalk

\section{INTRODUCTION}

The more advance establishment of the country leads to the more developed economic progress. Economic activities need good supporting infrastructures such as strategic market location and roadway to distribute the commodity in a city. Market and road become two main infrastructures that unite to support economic growth in a country.

On the twenty-fifths of February 2018, the fire of Banjarsari market caused damages to all stands and buildings. The government of Pekalongan relocated the Banjarsari market to some streets such as Patiunus, Belimbing, Rambutan, Mangga, and Soerogenen parks. This relocation interfered with the roadway and sidewalk function, and the pedestrians' needs were difficult to accommodate. 
The pedestrian facility consisted of three categories in general. 1) the main facility was a sidewalk that separated to the roadway, 2) crossing facilities such as zebra crossing and overpass, 3) bus station facilities such as benches and bus stop [1]. The three pedestrian facilities could not be used properly after the relocation of the Banjarsari market on Jalan Patiunus.

The sidewalk must be considered as one of the important elements in urban and regional planning [2]. A right sidewalk system gives a positive impact on the trade city, like stimulating trade activities, decreasing vehicle dependence, and increasing environment and air quality. The fact is sidewalk can exist in the city. Commonly, it spread out in trade areas such as on the right or left roadway, and many shops offered their goods, and at the end of the street, there was a plaza as a social center [3]

A good sidewalk needs some important aspects must be considered such as safety, joy, comfort, and attractiveness [4]. This elaboration confirms [2] which explained that the sidewalk needs a deep consideration in several aspects. Those aspects consist of 1) the balancing reciprocal between pedestrian and vehicle, 2) safety factor which includes adequate spaces for pedestrian, 3) the facilities that offered pleasure experience along the sidewalk, 4) public facilities that unite and support the sidewalk.

The crucial problem in urban planning was balancing between sidewalk and vehicle facilities. For example, the uptown pedestrian designed by the City of Charlotte, North Carolina, divided pedestrian zone problems into three categories: function and needs, psychological comfort, physical comfort. [5].

The direct influence of street vendors on city activities when viewed from the perspective of urban spatial planning discipline and city aesthetics / beauty has a negative impact [6]. The positive value that exists in the street vendors in Solo Grand Mall area is that they bring their own place or container to dispose of their waste products or garbage [6].

The City Walk route on Jalan Slamet Riyadi Surakarta has main facilities that meet the standards, such as pedestrian width, seating conditions and vegetation. There are only deficiencies in the cleanliness conditions and the availability of signs for groups of users with special needs. The biggest interference comes from the presence of illegal parking and street vendors [7].

Similar research [8], states that the commercial activities affect the function of roads and sidewalks. The government needs to separate spaces for pedestrians from street vendor activity spaces [8]. The citizen should be involved in the structuring process as well as seeing the standards and space requirements for pedestrians and other existing activities. The addition of open space as well as parking are needed to increase safety and comfort for pedestrians.

The Banjarsari relocation activities at Patiunus street caused pro and contra. The sellers who became a victims of Banjarsari market relocation gave positive reactions since they can open their shops along Patiunus street. On the other hand, the pedestrian and the citizen who passed daily in that area were disturbed with this relocation. These statements show that the activities of Banjarsari Market can affect the functions of road and of sidewalk.

From the facts described above, there are several exciting things to be investigated further: "How the impact of market relocation at Patiunus street toward roadway and sidewalk function". As for this research, this study aims to analyze the impact of market relocation at Patiunus street toward roadway and sidewalk function.

\section{METHODOLOGY}

This research used the qualitative descriptive method, and conducted three data collection techniques: direct observation, questionnaire, and documentation [9] This research was conducted in Patiunus street, at the roadway and sidewalk that was used for Banjarsari market relocation place.

Patiunus street sidewalk function was analyzed based on [2] theory (a. the balancing reciprocal between pedestrian and vehicle, $b$. safety factor including adequate spaces for pedestrian, $c$. the facilities offering pleasure experience along the sidewalk and $d$. public facilities that unite and support the sidewalk). The road function was analyzed based [10] regulation (a. secondary collector street was designed based on the speed design (no less than $20 \mathrm{~km} / \mathrm{h}$ ), b. the width of the standard road lane is not less than 9 meters, c. the road has sufficient equipment, $d$. the average daily traffic levels are generally the lowest in the primary system, e. secondary collector road connects between secondary areas; the second secondary area with the third secondary area, f. heavy vehicles are not permitted via this road function in residential areas, g. parking space was restricted).

Banjarsari market was in Sultan Agung Street Pekalongan. The market was on fire on the twenty-fifth of February 2018. All buildings were on-fire and damaged. The seller asked the government to relocate the Banjarsari market at Patiunus street as a temporary space [11] 


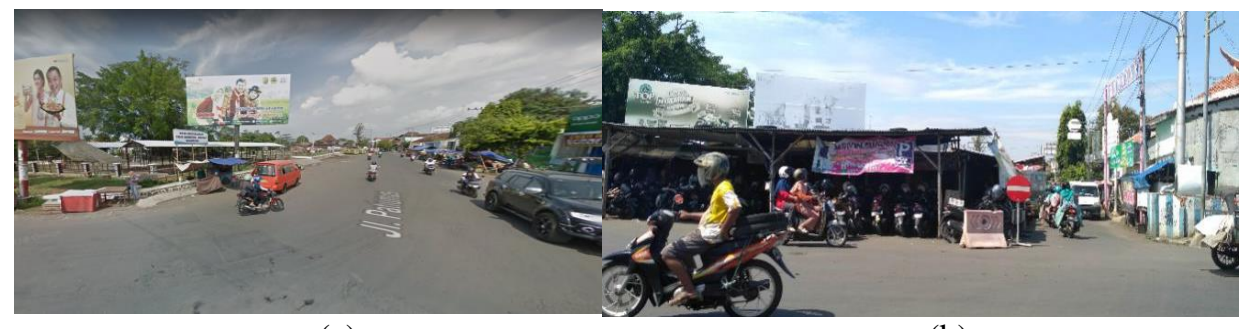

(a)

(b)

FIGURE 1. Patiunus street before (a) and after (b) Banjarsari Market relocation (Source: Researcher Documentation, 2019)

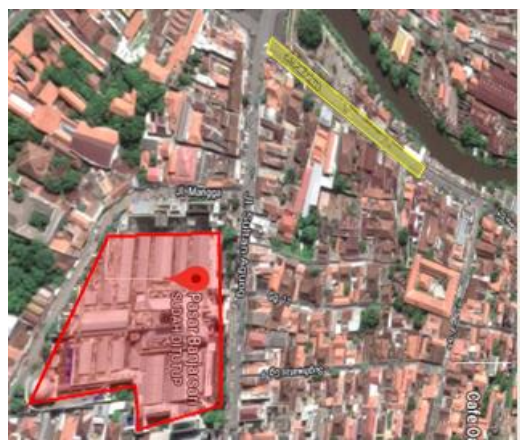

FIGURE 2. Map of Banjarsari market before conflagration (red line) and Patiunus street (yellow line). (Source: Google Maps)

Patiunus street was a secondary - collector street that was the center of local activities. There were street vendors who sold foods and fruits. Before conflagration occurred at Banjarsari market, at Patiunus Street there was an adequate parking area for the visitors who come to the Banjarsari market or Patiunus street vendors. Furthermore, Patiunus street is connected to the districts. Many people and vendor street disagree with this relocation, but the government chose that area for the temporary market of Banjarsari. Many shops were placed at Belimbing street, Mangga street, and Soerogenen park. The effect of this relocation brought Patiunus street was occupied with 518 vendors. These vendors consisted of 474 clothing and accessories vendors, 44 fruit, and vegetable vendors. Furthermore, Patiunus park was replaced by 295 vendors that consisted of 131 clothing and accessories vendors, 188 fruits and groceries vendors, 20 household goods vendors, and 41 food vendors [11]

\section{RESULT AND DISCUSSION}

Based on the street and road qualification regulation [12], Patiunus was categorized a secondary collector street. Furthermore, based on government low and administration, Patiunus street was classified as an urban road. Patiunus was included IIIC class based on axle load classification.

The secondary collector street is a road that connects the second secondary area with the second secondary area or connects the second secondary area with the third secondary area [10]. The characteristics of the secondary collector can be elaborated as follows, a. secondary collector street was designed based on the speed design (no less than $20 \mathrm{~km} / \mathrm{h}$ ), b. the width of the standard road lane no less than 9 meters, c. the road has sufficient equipment, $d$. the average daily traffic levels are generally the lowest in the primary system and secondary artery, e. secondary collector street is connected to the other primary street, the second secondary area with the third secondary area, f. heavy transports are not allowed to pass, g. parking space was restricted [10].

Patiunus street serves the public transportation route. This route can be elaborated as follows SayunSlamaran (round trips) as secondary taxi or van-stop. Patiunus is a two-way road with medium categories (length $544 \mathrm{~m}$; width $15 \mathrm{~m}$; lane $11,4 \mathrm{~m}$; left pavement $1,2 \mathrm{~m}$; right pavement 2,1 m; left road tunnel 0,5 $\mathrm{m}$; and 1,2 $\mathrm{m}$ of right road tunnel) [12]. 


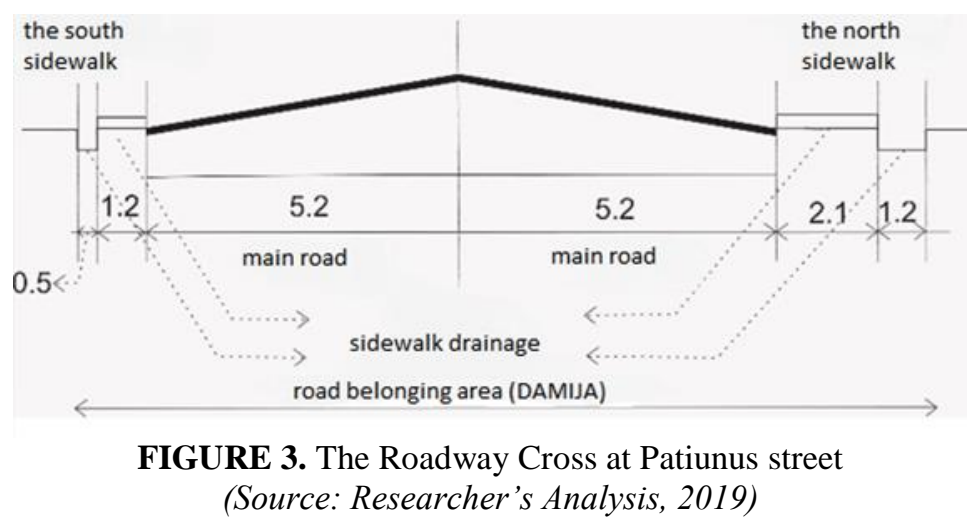

According to [12], Patiunus street is built and renovated with bus stops to support the transportation system. Also, the hour restriction to public transportation is implemented in a secondary bus-stop.

The function changed because of the functional frame [13]. The functional frame is a physical aspect of human behavior that always needs a space to accommodate their activities [13]. It changes as long as humans changed their lifestyle. The functional frame must adapt to the complexity of the activities [13]. The Banjarsari market relocation at Patiunus street and Patiunus parking areas caused transformation at the road function as economic activities placed.

\section{Discussion}

The discussion of the research divided into two parts based on the function secondary collector street [10] and the functions of sidewalk [2] Patiunus street is categorized as a secondary collector street that connects to each center activities such as the central national activities, region activities, district activities, and local activities to the center of environment activities [13].

The characteristics of Patiunus street as a secondary collector street had been changed in some aspects. [10] explained as follows.

a. A secondary collector street was designed based on the speed design (the speed must not exceed $20 \mathrm{kms} / \mathrm{h}$ )

The function of Patiunus street as a secondary collector street was not optimized because of the nonstandard width of the road. Furthermore, the average daily traffics, and the speed minimum $(20 \mathrm{kms} / \mathrm{h})$ cannot be achieved. The citizen preferred to use another way and avoided Patiunus street except for the resident who lived there.

\section{b. The width of the standard road lane is not less than 9 meters}

The road function tended to decrease since only 3 meters were left for the vehicle passing the street. The problem occurred when two cars came from the opposite way in Patiunus street. The cars needed to decrease their speed and find an adequate space to pass. The researcher found that there was only space from a whole Patiunus street that is possible to pass for the two cars from the opposite side. It was applied too for cars and pedicabs which come from the opposite lane.

\section{c. The road must have sufficient equipment}

Road equipment consists of traffic signs, road markings, traffic signaling devices, street lighting devices, road user control and safety devices, road surveillance and security devices, facilities for bicycles, pedestrians and persons with disabilities, and supporting facilities for traffic activities and road transportation found outside the road body [14]. Road equipment on Patiunus street includes traffic signs (warning signs, signposts, and forbidden signs), street lighting devices, pedestrian facilities and supporting facilities for road traffic and transportation activities found outside the road body, parking parks.

d. The average daily traffic levels are generally the lowest in the primary system and secondary artery.

Road benefit space that should be used for pavement, median strips, sidewalk, road drainage, heap and excavation, main road, road equipment, and so forth cannot be optimized at Patiunus street. Patiunus street was formerly planned for free space and the center of activities. However, it cannot be conducted now. 


\section{e. A secondary collector street connected to the other primer street}

Patiunus street which is located in the centre of the city, it connects the Jetayu historical area, to Banjarsari Market and Sugih waras settlement and other settlements to the east of Jalan Patiunus.

\section{f. Heavy transports were not allowed to pass}

Patiunus street was passed by public transportation which is crowded during rush hour. Heavy transports were not allowed to pass, because it is located at centre of Pekalongan city. This street cannot be passed by public transportation due to the relocation of Banjarsari market. This street was an important route that connected to the downtown of Pekalongan city. The street function diminished because of this relocation. Furthermore, the citizen who had to go to the market and the downtown cannot access this street.
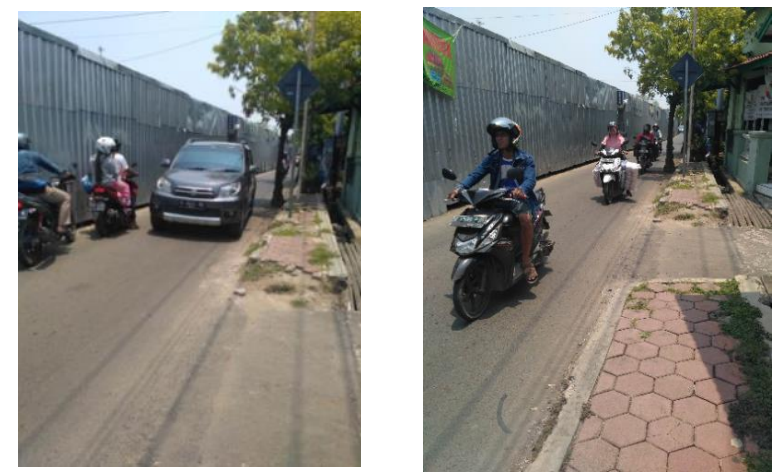

FIGURE 4. Vehicles which passed Patiunus Street (Researcher Documentation, 2019)

Until 2020, Patiunus street was inaccessible to freight cars, and garbage trucks needed to turn around for picking the trash. Traffic Jammed became familiar to the people in passing this street, and the alley of Patiunus street transformed to be the shortcut route show in Figure 4. The urban accessibility function tended to decrease and spent more time to pass this street because of Banjarsari market relocation.

\section{g. Parking space was restricted}

Patiunus steet as a local collector road is restricted for parking space. Therefore, Patiunus Parking Park was created to support the surrounding activities on Jalan patiunus. Patiunus Parking Park was created to support commercial activities at Banjarsari Market and public transport terminals on Patiunus street.

The relocation of Banjarsari market took more than half of the main road and the road space. Figure. 5 shows the north sidewalk and Patiunus Parking area achieved the standard regulation of the sidewalk (right side of Figure.5). However, this part was used to relocate the Banjarsari market. The north sidewalk had 2 metres of width, and the south sidewalk was eless than 1 metre of width. Furthermore, there was a section of unavailable sidewalk near the market on the south sidewalk of Patiunus street (left side of Figure.5)

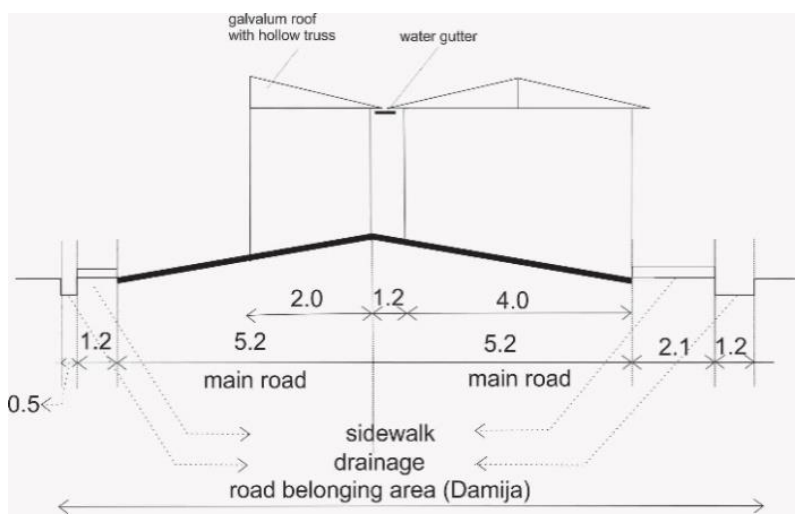

FIGURE 5. The illustration of Banjarsari market relocation at Patiunus street (Source: Researcher's Analysis, 2019) 
Figure 5 shows the road part of Patiunus street according to [15]. Then, add by the illustration of temporary stands for Banjarsari market relocation. The north side of Patiunus was covered by stands, while the south sidewalk was covered by many potholes and non-standard. It causes the pedestrians and visitors to use the main road of Patiunus street.

The picture above was a road part based on [15].

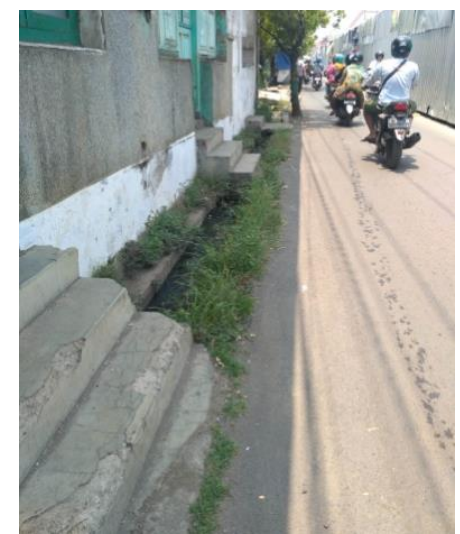

FIGURE 6. The North Sidewalk Condition at Patiunus Street (Researcher Documentation, 2019)

The sidewalk of Patiunus street was covered by the Banjarsari market, and it was the south sidewalk remaining as shown on Figure 6. This situation did not meet the sidewalk criteria proposed by [2]

1. The balancing interaction between the pedestrians and the vehicles. Figure 7 shows that the pedestrian prefers to use the main road to avoid the potholes and street vendors that utilized the sidewalk.

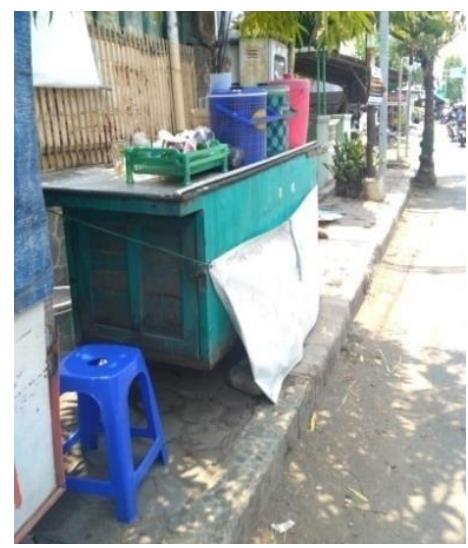

FIGURE 7. Street Vendor at the south sidewalk of Patiunus street

(Researcher's Documentation, 2019)

2. Safety factor, adequate space for pedestrians. The pedestrians at Patiunus street were not safe since there were many street vendors and potholes that need some improvements. The north sidewalk of Patiunus street had 2 metrese of width. On the other hand, the south sidewalk had 1 metre of width, and some of the parts did not have a sidewalk. Most of the drainage at Patiunus street was broken, which caused a flood when the rainy season comes. Furthermore, the puddles can overflow and cover Patiunus street. This condition in Figure. 8 weakens the pavement structure and the safeness of visitors. 


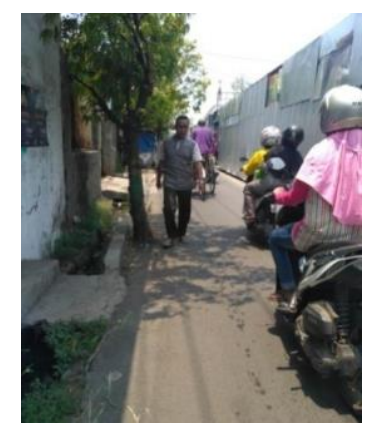

FIGURE 8. The Pedestrian looked uncomfortable when he had to use the road.

(Researcher's Documentation 2019)

3. The facilities offered a pleasurable experience on the sidewalk. There were many trees on Patiunus street. Unfortunately, there were not sufficient street signs for the disabled person. Furthermore, the quality of the sidewalk needed some improvement.

4. The availability of public facilities unites and becomes supporting elements of the sidewalk. In the beginning in Figure 9 a) several facilities support Patiunus streets like parks and benches. However in Figure $9 \mathrm{~b}$ ) those facilities cannot be used after the relocation of the Banjarsari market.

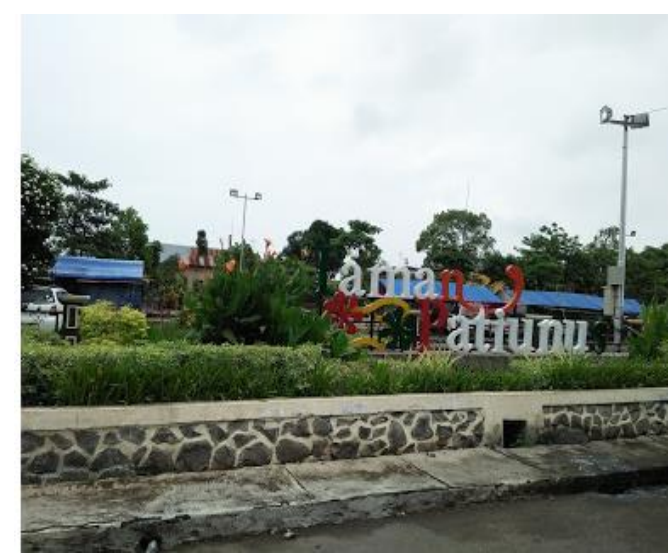

(a)

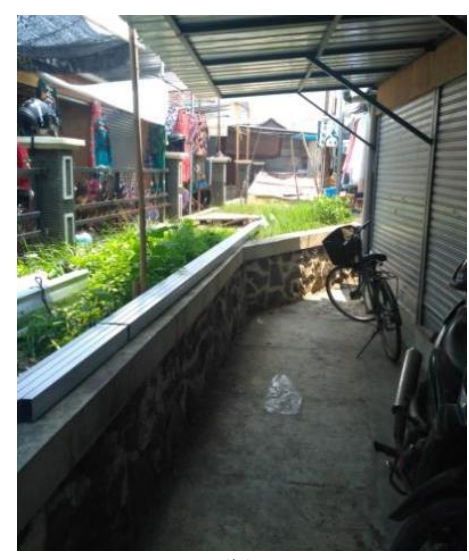

(b)

FIGURE 9. Patiunus Parking Area (a) before relocation, (b) After relocation Banjarsari market. (Source Google Maps and Researcher's Documentation, 2019)

The condition of Patiunus street that functions of secondary collector street was failed to achieve. Redesign the sidewalk and reorganization of the street vendors were required to employ the comfort and safety of visitors. It maintained pedestrians for not using the main road to walk. It provided safety and comfort to them and could decrease the number of accidents in Patiunus street. The pavement structures became weakened because of puddles from poor drainage. It became uncomfortable to pedestrians and vehicle users.

The government may change the road status from secondary collector street to secondary street if the market is overflown and crowded. It explained at [16] regulation that stated several possible conditions to change the road function in an urban area; 1 . The road status can be changed to another road function, 2. The increasing traffic volume, 3. The decreasing of role road and or the width limit of the road, 4 . The changing status of the road can be proposed by the former committee to a new committee that can accept the new status of the road. The four factors can influence the road status of Patiunus street, from a secondary collector street to a secondary street. However, reconstruction and rebuilding of the Banjarsari market was needed to execute so that the principal function of Patiunus street will not be dis-sappier and inline with [12] 


\section{CONCLUSION}

The relocation of Banjarsari market at Patiunus street changed the function of the sidewalk. The function changed and did not the same as the former design of secondary collector street. The pedestrians' safety tends to decrease since one of the pavement sides was covered by street vendors, while another side was worse and nonstandard.

The researcher proposed some recommendations as follows:

1. The improvements of the sidewalk at the south park and redesign for the street vendor are required. It aims to prevent visitors and pedestrians for not using the main road to walk. It brings safety and comfort to them and could decrease the number of accidents in Patiunus street.

2. The government may change the road status from secondary collector street to secondary street if the market is overflown and crowded.

3. A proper drainage system needs to be planned since the water is overflown and results in puddles. It is urgent to be solved since it disturbed the surface course of pavement structures.

\section{REFERENCES}

[1] Haryanti, Dini Tri, "Kajian Pola Pemanfaatan Ruang Terbuka Publik Kawasan Bundaran Simpang Lima Semarang", M.S. Thesis, Deptement of Urban Planning. Diponegoro University. 2008

[2] Shirvani, H., The Urban Design Process. Van Nonstrand Reinhold. 1985

[3] Rubenstein, Harvey M.. Central City Malls. New York : John Wiley \& Sons. 1987

[4] Utterman, RK.. Accomodating The Pedestrian. New York : Van Nostrad Reinhold Co. 1984

[5] City of Charlotte, The Uptown Pedestrian., Charlotte: NC., 1978.

[6] Iswanto, Danoe. "Tinjauan Keberadaan Pedagang Kaki Lima (PKL) Aspek Pedestrian Area, dan Area Parkir di Kawasan Solo Grand Mall (SGM). J. Perancangan Kota dan Permukiman. ENCLOSURE. vol. 6, no. 2, p. $79-86,2007$

[7] K. Harsono, Y. Arsandrie and W. Setiawan, "Identifikasi Kenyamanan Pejalan Kaki di City Walk Jalan Slamet Riyadi Surakarta". J. Arsit. Sinektika. vol. 1, no. 1, p. 33-42, 2013

[8] Ariwibowo, M. Arief, "Penataan Jalur Pejalan Kaki Pada Koridor Jalan Malioboro Berdasarkan Persepsi dan Preferensi Pengunjung”. M.S. Thesis, Departement of Urban Planning. Diponegoro University. 2008]

[9] Sugiyono. 2012. Metode Penelitian Kuantitatif Kualitatif dan R\&B. Bandung: Alfabeta.

[10] Indonesia. Indonesia Government Reguation No. 101/t/BNKT/1990 The Guidelines for Determining Road Functional Classification in Urban Area.Jakarta: Indonesia Government Reguation. 1990

[11] Radar Pekalongan. 2018. https://radarpekalongan.co.id/26695/zonasi-pedagang-pasar-daruratditetapkan/. Access at July, 82019.

[12] Indonesia. Pekalongan City Government. Peraturan Daerah Kota Pekalongan Nomor 30 Tahun 2011 Tentang Rencana Tata Ruang Wilayah Kota Pekalongan Tahun 2009-2029. Pekalongan: Pekalongan City Government. 2011

[13] Surasutedja.. Fungsi, Ruang, Bentuk dan Ekspresi Dalam Arsitektur. Jakarta: UPI. 2007

[14] Indonesia. President of Republic of Indonesia. Undang-Undang Republik Indonesia Nomor 22 Tahun 2009 tentang Lalu Lintas dan Angkutan Jalan. Jakarta: President of Republic Indonesia. 2009

[15] Indonesian Government Regulation No. 34 Year 2006, Road issued. 2006

[16] Indonesia. The Ministry of Public Works Regulation. The Ministry of Public Works Regulation Number 03 Year 2012 about the Guideline of Road Function and Road Status. Jakarta: The Ministry of Public Works Regulation 2012 